\title{
GAMBARAN PERUBAHAN AKTIVITAS DAN DIET PADA PASIEN POST KATETERISASI JANTUNG
}

\author{
Essa Widya Pertiwi ${ }^{1}$, Erwin $^{2}$, Wan Nishfa Dewi ${ }^{3}$ \\ ${ }^{1,2,3}$ Fakultas Keperawatan Universitas Riau \\ Fakultas Keperawatan Universitas Riau Jalan Pattimura No 9 Gedung G Pekanbaru Riau \\ Kode Pos 28131 Indonesia \\ emailwidiawidia707@gmail.com
}

\begin{abstract}
Abstrak
Tujuan penelitian ini adalah mengetahui gambaran perubahan aktivitas dan diet pada pasien post kateterisasi jantung. Metode penelitian ini bersifat kuantitatif dengan desain penelitian deskriptif. Metode pengambilan sampel adalah accidental sampling dengan jumlah responden 30 orang. Alat ukur yang digunakan adalah kuesioner yang telah di uji konten validitas dan reliabilitas. Hasil penelitian ini menunjukkan adanya perubahan aktivitas sebelum dan setelah melakukan tindakan kateterisasi jantung terkait pola dan intensitas aktivitas serta diet. Sebelum kateteriasasi jantung aktivitas terkait pola aktivitas dasar adalah ketergantungan berat (50\%) dan setelah kateteriasi jantung menjadi mandiri (100\%). Intensitas aktivitas sebelum dan setelah kateterisasi adalah intensitas rendah dengan persentase sebelum melakukan tindakan kateterisasi jantung $(56,7 \%)$ dan setelah kateterisasi (100\%). Diet makanan berkolesterol sebelum kateterisasi 3-6x/minggu $(56,7 \%)$ dan setelah kateteriasi jantung 2x/bulan (80\%). Konsumsi makanan berserat sebelum dan setelah melakukan kateterisasi jantung adalah 3-6x/minggu dengan persentase sebelum kateterisasi jantung $(46,7 \%)$ dan setelah kateterisai jantung $(73,3 \%)$. Konsumsi makanan berprotein nabati sebelum dan setelah kateterisasi jantung adalah 3-6x/minggu dengan persentase sebelum kateterisasi $(46,7 \%)$ dan setelah kateterisasi $(56,7 \%)$. Konsumsi makanan bervitamin sebelum kateterisasi adalah 1-2x/minggu (76,7\%) dan setelah kateterisasi 3-6x/minggu (60\%). Hasil penelitian ini diharapkan dapat menjadi masukan untuk penderita penyakit jantung koroner agar dapat memanajemen aktivitas dan diet sehingga terdapat perubahan dalam aktivitas dan diet tersebut.
\end{abstract}

Kata kunci: Aktivitas, diet, kateterisasi jantung

\section{Abstract}

The aim of this study is to find out the overview of changes in activity and diet on patient with post cardiac catheterization. Research design used for this study was quantitative with descriptive design. Accidental sampling method was used to collect the sample with total of 30 respondents. Measuring instrument used was questionnaire which had been tested related to its validity and reliability. This study result shows changes of activities before and after cardiac catheterization treatment related to diet activities pattern and intensity. Before the cardiac catheterization treatment 
Essa Widya Pertiwi, Erwin, Wan Nishfa Dewi, Gambaran Perubahan Aktivitas dan Diet pada Pasien Post Kateterisasi Jantung

related to basic activity pattern is heavy dependent (50\%) and after the treatment it becomes independent (100\%). The intensity of activities before and after catheterization show low intensity with percentage of $(56.7 \%)$ cardiac catheterization treatment and after the treatment it becomes (100\%). Cholesterol diet 3-6x/week before catheterization is (56.7\%) and after 2x/month cardiac catheterization (80\%). Consuming fibrous foods before and after cardiac catheterization is $3-6 x /$ week with a percentage of $(46,7 \%)$ before cardiac catheterization and after cardiac catheterization is $(73.3 \%)$. Consuming vegetables before and after cardiac catheterization is 3-6x/week with the percentage of $(46,7 \%)$ before catheterization and after catheterization is (56.7\%). Consuming vitamin foods before catheterization is $1-2 x /$ week $(76.7 \%)$ and after 3-6x/week catheterization (60\%). This study result is expected to become a suggestion for coronary heart disease patient in the purpose of the management of their activities and diet, so it will have changes in related activities and diet.

Keywords: Activity, cardiac catheterization, diet

\section{PENDAHULUAN}

Jantung adalah salah satu organ vital yang penting bagi tubuh manusia. Jantung berfungsi memompa darah untuk memenuhi kebutuhan suplai oksigen bagi seluruh jaringan (Udjianti, 2011). Bertugas untuk mengangkut darah yang kaya akan oksigen ke jantung di sebut arteri koronaria. Oleh otot-otot jantung, oksigen tersebut digunakan untuk respirasi, sehingga jantung dapat terus memompa darah ke seluruh tubuh. Jika terjadi penyempitan di arteri koronaria maka oksigen tidak dapat disalurkan dengan baik ke otot-otot jantung, akibatnya jantung menjadi lemah dan tidak dapat memompa darah

keseluruh tubuh. Penyempitan arteri koronaria biasanya disebabkan oleh atheriosclerosis (Widiyanto, 2014).

Kematian yang diakibatkan oleh penyakit kardiovakuler menempati urutan pertama di dunia, sehubung dengan angka prevalensi penderita penyakit jantung yang semakin meningkat. Pada tahun 2016 diperkirakan sekitar 17,9 juta orang meninggal dunia akibat penyakit kardiovaskuler atau $31 \%$ dari seluruh kematian di dunia (WHO, 2017).

Mengingat tingginya angka kejadian penyakit kardiovaskuler ini, perlu dilakukan pendeteksian sedini mungkin agar dapat ditindaklanjuti dengan melakukan 
pemeriksaan dan konsultasi. Pemeriksaan dan konsultasi oleh dokter spesialis jantung dapat mengetahui penyakit jantung koroner, pemeriksaan tersebut seperti Calcium Scoring. Jantung (CAT Scanning) selanjutnya ditindaklanjuti dengan pemeriksaan ECG, Treadmill Test dan Kateterisasi (Irianto, 2014).

Apabila setelah dilakukan pemeriksaan ditemukan penyempitan, maka akan dilakukan tindakan operasi jantung terbuka untuk memasang pembuluh darah baru menggantikan pembuluh darah yang tersumbat disebut Coronary Artery Bypass Surgery (CABG) atau dilakukan tindakan pelebaran pembuluh darah jantung yang menyempit dengan metode Percutaneous Transluminal Coronary Angioplasty (PCTA) (Irianto, 2014).

Pasien yang dilakukan tindakan

Percutaneous Coronary Intervention (PCI) biasanya akan di rawat inap selama satu malam untuk diobservasi (Darliana, 2012). Hasil penelitian yang dilakukan oleh Sukmawati, Setyawan dan Widianto (2016) sebelum intervensi sebagian besar responden mengalami ketergantungan total dikarenakan pasien tersebut harus di immobilisasikan sekitar 12 jam dalam posisi telentang dan ekstremitas bawah tidak boleh ditekuk. Akibatnya pasien tidak dapat melakukan aktivitas.

Aktivitas sehari-hari adalah istilah yang digunakan untuk menggambarkan kegiatan sehari-hari seperti perawatan diri yang dilakukan ketika berada dirumah, di lingkungan luar ataupun keduanya (Aryapost, 2016).

Pasien post kateterisasi jantung perlu meningkatkan aktivitas sehari-hari. Aktivitas pada pasien post kateterisasi jantung dapat ditingkatkan dengan cara salah satunya yaitu tindakan ambulasi dini. Ambulasi dini adalah tindakan keperawatan segera yang harus dilakukan setelah pasca operasi yang mempunyai manfaat dalam meningkatkan aktivitas sehari-hari dan mencegah komplikasi pasca operasi (Sukmawati, 2016). Hasil penelitian Hutagalung, Susilaningsih dan Mardiyah (2014) kondisi pasien pasca 
Essa Widya Pertiwi, Erwin, Wan Nishfa Dewi, Gambaran Perubahan Aktivitas dan Diet pada Pasien Post Kateterisasi Jantung

dilakukan tindakan intervensi mengukur efikasi diri pasien dalam menjalani aktivitas sehari-hari yang berubah pasca tindakan terkait pengobatan, diet, dan aktivitas. Menurut American Heart Association kebanyakan pasien kateterisasi jantung sudah bisa beraktivitas normal sehari setelah melakukan prosedur kateterisasi (AHA, 2015).

Penyakit kardiovaskular dapat terjadi karena salah satu faktor resikonya adalah dari kebiasaan makan dan asupan diet yang kurang baik sehingga berdampak pada hiperkolesterolemia dan hiperlipidemia. Beberapa penelitian menyebutkan bahwa kebiasaan makan pada usia dewasa memiliki hubungan yang signifikan terhadap terjadinya obesitas dan meningkatnya resiko penyakit jantung akibat penumpukan lemak dan pembuluh darah (Al Muammar et al, 2014).

Studi pendahuluan dilakukan di ruangan poli jantung RSUD Arifin Achmad pada tanggal 12-16 November 2018, didapatkan 8 orang pasien jantung koroner yang telah melakukan kateterisasi jantung.
Berdasarkan wawancara yang telah dilakukan 3 dari 8 pasien pada hari pertama setelah melakukan kateterisasi jantung memerlukan bantuan pada saat melakukan aktivitas seperti makan, mandi, berpakaian, naik turun tangga dan berpindah, namun selanjutnya sudah dapat melakukan aktivitas tersebut dengan mandiri. Sedangkan 5 dari 8 pasien mengatakan hanya memerlukan bantuan pada saat diruang pemulihan 8-12 jam setelah post kateterisasi, namun ketika sudah pulang kerumah sudah dapat melakukan aktivitas sehari-hari. Walaupun dapat melakukan aktivitas 8 pasien mengatakan tidak dapat mengangkat benda yang berat maupun melakukan aktivitas yang berat, untuk makanan 5 orang mengatakan membatasi konsumsi makanan yang tidak dianjurkan seperti makanan berkolesterol sedangkan 3 orang lagi tidak membatasi atau tidak memiliki pantangan dalam memilih makanan. Berdasarkan penjelasan yang telah dikemukakan, maka peneliti tertarik untuk meneliti "Gambaran perubahan aktivitas dan diet pada pasien post kateterisasi jantung”. 


\section{METODE PENELITIAN}

Penelitian ini menggunakan desain penelitian deskriptif sederhana untuk menggambarkan atau deskripsi tentang rerata suatu variabel (Dahlan, 2010).

Data dikumpulkan menggunakan kuesioner/checklist. Kuesioner dibacakan oleh peneliti berjumlah sebanyak 38 pertanyaan yang merupakan modifikasi kuesioner yang telah ada.

Sebelum kuesioner dibagikan, terlebih dahulu peneliti melakukan uji validitas dan reliabilitas. Kuesioner telah valid dan reliabel dengan jumlah soal 38 pertanyaan. 10 pertanyaan tentang pola aktivitas dengan Cronbach alpha (0,932), 10 pertanyaan tentang intensitas aktivitas dengan Cronbach alpha $(0,954)$, dan 18 pertanyaan tentang diet dengan Cronbach alpha $(0,950)$.

\section{HASIL PENELITIAN}

\section{Karakteristik responden}

\section{Tabel 1}

Distribusi karakteristik responden

\begin{tabular}{|c|c|c|}
\hline \multirow[t]{2}{*}{ Karakteristik } & \multicolumn{2}{|l|}{$(\mathrm{N}=30)$} \\
\hline & $\mathrm{N}$ & $\%$ \\
\hline \multicolumn{3}{|l|}{ 1. Umur } \\
\hline 46-55 Tahun & 11 & 46,7 \\
\hline 56-65 Tahun & 5 & 36,7 \\
\hline$>65$ Tahun & 5 & 16.7 \\
\hline \multicolumn{3}{|l|}{ 2. Jenis Kelamin } \\
\hline Laki-laki & 24 & 80 \\
\hline Perempuan & 6 & 20 \\
\hline \multicolumn{3}{|l|}{ 3.Tingkat Pendidikan } \\
\hline SD/tidak tamat SD & 6 & 20 \\
\hline SMP & 3 & 10 \\
\hline SMA & 8 & 30 \\
\hline Akademi & 12 & 40 \\
\hline \multicolumn{3}{|l|}{ 4.Pekerjaan } \\
\hline PNS & 5 & 16,7 \\
\hline Wiraswasta & 10 & 33,3 \\
\hline Tidak bekerja & 6 & 20 \\
\hline Lainnya & 9 & 30 \\
\hline \multicolumn{3}{|l|}{ 5.Waktu Kateterisasi } \\
\hline November 2018 & 4 & 13,3 \\
\hline Desember 2018 & 7 & 23,3 \\
\hline Januari 2019 & 5 & 16,7 \\
\hline Februari 2019 & 3 & 10 \\
\hline Maret 2019 & 5 & 16,7 \\
\hline April 2019 & 6 & 20 \\
\hline \multicolumn{3}{|l|}{ Jumlah ring } \\
\hline 1 & 13 & 43,3 \\
\hline 2 & 14 & 46,7 \\
\hline 3 & 3 & 10 \\
\hline Total & 30 & 100 \\
\hline
\end{tabular}


Essa Widya Pertiwi, Erwin, Wan Nishfa Dewi, Gambaran Perubahan Aktivitas dan Diet pada Pasien Post Kateterisasi Jantung

Tabel 1 menjelaskan bahwa sebagian besar responden berusia 46-55 tahun $(46,7 \%)$, dari 30 responden yang diteliti paling banyak berjenis kelamin terbanyak laki-laki (80\%), dengan tingkat pendidikan terbanyak adalah akademi/ perguruan tinggi (40\%), memiliki pekerjaan terbanyak wiraswasta $(33,3 \%)$, waktu dilakukan kateterisasi sebagian besar pada bulan Desember 2018 (23,3\%) dan jumlah pemasangan ring terbanyak adalah 2 buah $(46,7 \%)$.

\section{Tabel 2}

Distribusi responden berdasarkan aktivitas pola dan intensitas sebelum dan setelah kateterisasi

\begin{tabular}{lllll}
\hline Aktivitas & \multicolumn{2}{l}{$\begin{array}{l}\text { Sebelum } \\
\text { katetetisasi }\end{array}$} & \multicolumn{2}{l}{ kateterisasi } \\
\cline { 2 - 5 } & $\mathrm{n}$ & $\%$ & $\mathrm{n}$ & $\%$ \\
\hline $\begin{array}{l}\text { 1.Pola } \\
\text { Mandiri }\end{array}$ & 3 & 10 & 30 & 100 \\
Ketergantung- & 12 & 40 & 0 & 0 \\
an ringan & & & & \\
Ketergantung- & 15 & 50 & 0 & 0 \\
an berat & & & & \\
\hline 2.Intensitas & & & & \\
Intensitas & 13 & 43,3 & 0 & 0 \\
tinggi & & & & \\
Intensitas & 17 & 56,7 & 30 & 100 \\
rendah & & & & \\
\hline Total & 30 & 100 & 30 & 100 \\
\hline
\end{tabular}

Tabel 2 menjelaskan tentang distribusi responden berdasarkan aktivitas terkait pola aktivitas dan intensitas aktivitas sebelum dan setelah kateterisasi jantung. Sebelum kateterisasi didapatkan hasil untuk pola aktivitas mayoritas responden mengalami ketergantungan berat $(50 \%)$ dan intensitas aktivitas adalah intensitas rendah $(56,7 \%)$. Setelah kateterisasi didapatkan hasil untuk pola aktivitas bahwa mayoritas responden mandiri (100\%) dan intensitas aktivitas nya adalah intensitas rendah (100\%).

\section{Tabel 3}

Distribusi responden diet sebelum dan setelah kateterisasi jantung

\begin{tabular}{lllll}
\hline Diet & \multicolumn{2}{l}{$\begin{array}{l}\text { Sebelum } \\
\text { katetetisasi }\end{array}$} & \multicolumn{2}{l}{ kateterisasi } \\
\cline { 2 - 5 } & $\mathrm{n}$ & $\%$ & $\mathrm{n}$ & $\%$ \\
\hline 1.Kolesterol & & & & \\
1x/hari & 2 & 6,7 & 0 & 0 \\
3-6x/minggu & 17 & 56,7 & 0 & 0 \\
1-2x/minggu & 9 & 30 & 6 & 20 \\
2x/bulan & 2 & 6,7 & 24 & 80 \\
\hline 2.Serat & & & & \\
1x/hari & 6 & 20 & 4 & 13,3 \\
3-6x/minggu & 14 & 46,7 & 22 & 73,3 \\
1-2x/minggu & 9 & 30 & 4 & 13,3 \\
2x/bulan & 1 & 3,3 & 0 & 0
\end{tabular}




\begin{tabular}{lllll}
\hline Diet & \multicolumn{2}{l}{$\begin{array}{l}\text { Sebelum } \\
\text { katetetisasi }\end{array}$} & \multicolumn{2}{l}{$\begin{array}{l}\text { ketelah } \\
\text { kateterisasi }\end{array}$} \\
\cline { 2 - 5 } & $\mathrm{n}$ & $\%$ & $\mathrm{n}$ & $\%$ \\
\hline 3.Protein & & & & \\
nabati & & & & \\
1x/hari & 2 & 6,7 & 11 & 36,7 \\
3-6x/minggu & 14 & 46,7 & 17 & 56,7 \\
1-2x/minggu & 9 & 30 & 2 & 6,7 \\
2x/bulan & 5 & 16,7 & 0 & 0 \\
\hline 4.Vitamin & & & & \\
1x/hari & 0 & 0 & 12 & 40 \\
3-6x/minggu & 7 & 23,3 & 18 & 60 \\
1-2x/minggu & 23 & 76,7 & 0 & 0 \\
2x/bulan & 0 & 0 & 0 & 0 \\
\hline Total & 30 & 100 & 30 & 100 \\
\hline
\end{tabular}

Table 3 menjelaskan tentang distribusi diet sebelum dan setelah kateterisasi jantung. Didapatkan hasil sebelum kateterisasi jantung konsumsi makanan kolesterol responden mayoritas $3-6 x /$ minggu $\quad(56,7 \%)$. Setelah dilakukan kateterisasi jantung konsumsi makanan berkolesterol responden menurun menjadi 2x/bulan (80\%).

Konsumsi makanan berserat pada responden sebelum katetrisasi mayoritas adalah 3-6x/minggu $(46,7 \%)$ dan setelah dilakukan tindakan kateterisasi jantung 3-6x/minggu $(73,3 \%)$.

Konsumsi makanan berprotein nabati sebelum dilakukan kateterisasi jantung

mayoritas adalah 3-6x/minggu (46,7\%) dan setelah dilakukan tindakan kateteriasi jantung $3-6 x / \operatorname{minggu}(56,7 \%)$.

Konsumsi makanan bervitamin sebelum dan setelah dilakukan tindakan kateteriasi jantung adalah 1-2x/minggu (76,7\%). Setelah dilakukan kateteriasi meningkat menjadi 3-6x/minggu (60\%).

\section{PEMBAHASAN}

A. Pembahasan hasil penelitian

\section{Karakteristik responden}

\section{a. Umur}

Hasil penelitian yang telah dilakukan pada pendrita penyakit jantung yang menjalani prosedur kateterisasi jantung didapatkan bahwa sebagian besar berusia antara 46-55 tahun. Semakin tua umur maka semakin besar kemungkinan timbulnya plak yang menempel di dinding dan menyebabkan mengganggu aliran darah yang melewatinya. Penyakit jantung koroner yang diakibatkan oleh individu yang tidak bisa mengontrol kadar kolesterol didalam darah dalam jangka waktu yang lama sehingga penyakit ini berdominan 
Essa Widya Pertiwi, Erwin, Wan Nishfa Dewi, Gambaran Perubahan Aktivitas dan Diet pada Pasien Post Kateterisasi Jantung

terjadi pada orang yang berusia lebih dari 45 tahun (Hidayat, 2015).

\section{b. Jenis kelamin}

Laki-laki dan perempuan berbeda gaya hidup maupun kebiasaanya, pada kasus penyakit jantung pasien yang ditemukan melakukan kateterisasi jantung kebanyakan adalah laki-laki. Hal ini disebabkan karna laki-laki memiliki faktor risiko lebih tinggi menderita penyakit jantung koroner terkait dengan pola atau gaya hidup seperti kebiasaan merokok, minum kopi, serta kurang olahraga (Sukmawati, Setyawan \& Widyanto, 2016).

\section{c. Tingkat pendidikan}

Tingkatan pendidikan yang didapat seseorang tidak menjamin status kesehatan, namun secara umum berdasarkan hasil penelitian pendidikan terakhir responden yang menjalani prosedur kateterisasi jantung paling banyak yaitu akademi/perguruan tinggi. Meskipun demikian, pendidikan tinggi tidak menjamin semua orang untuk mendapat pengetahuan tentang kesehatan baik itu tentang jantung maupun tentang pencegahan penyakit lainnya.

Semakin tinggi jengang pendidikan akan mempengaruhi jenis pekerjaan dan mempengaruhi gaya hidup individu dan kemampuan tuntuk mengelola diri sesuai dengan pengetahuan yang didapat (Rochmayanti, 2013).

\section{d. Pekerjaan}

Orang yang memiliki pekerjaan atau kesibukan sering kali lupa untuk memperhatikan kesehatannya, dengan kesibukan yang padat orang sering kali mengabaikan diri dan tidak sempat untuk berolahraga. Pada penelitian ini didapatkan mayoritas adalah orang yang melakukan kateterisasi ini adalah wiraswasta. Hasil penelitian ini dikukung oleh oleh Iskandar (2017) yang menunjukkan bahwa orang yang bekerja sebagai wiraswasta/pedagang dan Pegawai Negri Sipil lebih banyak yang terkena penyakit jantung koroner.

\section{e. Waktu Kateterisasi}

Tindakan kateterisasi jantung dapat dilakukan lebih dari sekali. Pada penelitian ini 
kebanyakan responden melakukan kateterisasi pada bulan Desember 2018. Pada responden yang pernah menjalani kateterisasi jantung bila tidak menerapkan pola hidup yang baik, dan menjalani diet sehat untuk penyakit jantung maka akan besar resiko untuk dilakukan kateterisasi jantung berulang.

Penelitan Harun, Ibrahim, dan Rafiah (2016) mengatakan bahwa setelah menjalanin kateterisasi jantung petugas kesehatan akan memberikan pendidikan kesehatan dan rekomendasi untuk menjaga pola hidup sehat, kepatuhan pasien terhadap rekomendasi dan perawatan dari petugas kesehatan penting untuk keberhasilan dari tindakan tersebut.

\section{f. Jumlah Ring}

Pasien yang telah melakukan tindakan pemasangan ring jantung (stent) dapat mengalami serangan jantung kembali karena terjadi re-stenosis yang disebut in stent re-stenosis. Hal ini merupakan penyempitan kembali pembuluh (Kraitzer, Kloog, \& Zilberman, 2007). Sehingga terkadang banyak responden yang telah mempunyai 2 atau lebih ring jantung (stent).
Susanti, Nurachmah dan Herawati (20) menyatakan bahwa tidak terdapat hubungan antara kejadian tindakan kateterisasi berulang dengan usia, jenis kelamin, jumlah stent maupun durasi pemasangan PCI, namun faktor dominan terjadinya tindakan pemasangan stent berulang ini adalah pola hidup seperti kebiasaan merokok.

\section{Gambaran aktivitas dan diet}

a. Pola aktivitas dan intensitas aktivitas

Pasien jantung ketika mengalami sesak tidak dapat beraktivitas dengan baik sehingga memerlukan bantuan. Setelah melakukan kateterisasi jantung pasien akan diobservasi selama kurang lebih 6 jam atau dirawat inap selama satu malam dan setelah itu diperbolehkan untuk pulang (Darliana, 2012). American Heart Association menyatakan bahwa kebanyakan pasien kateterisasi jantung sudah bisa beraktivitas normal sehari setelah melakukan prosedur kateterisasi (AHA, 2015).

Hasil penelitian Pradono dan Werdhasari (2017) menyatakan bahwa orang dengan 
Essa Widya Pertiwi, Erwin, Wan Nishfa Dewi, Gambaran Perubahan Aktivitas dan Diet pada Pasien Post Kateterisasi Jantung

aktivitas yang rendah lebih tinggi persentase untuk terkena penyakit jangung koroner dari pada mereka yang beraktivitas cukup. Aktifitas fisik atau olahraga yang teratur mengurangi risiko terjadinya penyakit arteri coroner. Selain itu olahraga juga mengurangi beberapa faktor risiko terhadap PJK, seperti: kolesterol tinggi, hipertensi, obesitas, dan meningkatkan HDL.

Banyak penelitian menyatakan, kurang aktif bergerak pengaruhnya pada risiko PJK sama tingkatannya pada pria atau wanita. Pada orang-orang bugar umumnya faktor-faktor risiko mereka terkendali dengan baik, jantungnya lebih besar dan lebih kuat, yang mempengaruhi pada peningkatan suplai darah dan oksigen. Latihan-latihan olahraga selama 30 menit setiap kali berlatih dengan intensitas sedang sudah dapat menurunkan risiko PJK (Waspadji, Suyono \& Sukarji, 2010).

b. Diet

Penyebab tinggi terjadinya PJK dan memperberat PJK ialah peningkatan kadar kolestrol dalam darah. Hasil penelitian
Zahrawardani (2013) menyatakan bahwa terdapat hubungakan yang bermakna antara kolesterol total dengan kejadian penyakit jantung koroner. Kadar kolesterol yang tinggi dapat mengendap di dalam pembuluh arteri yang menyebabkan penyempitan dan pengerasan yang dikenal sebagai atherosklerosis atau plak. Akibat meningginya beban kerja jantung dan hipertrofi, maka kebutuhan jantung akan darah (oksigen) meningkat dan menyebabkan terjadinya PJK. Oleh sebab itu perlunya mengurangi konsumsi makanan berkolesterol pada pasein yang mempunyai riwayat jantung koroner.

Selain mengurangi konsumsi makanan yang berkolesterol tinggi kebutuhan pangan tinggi serat makanan dan pangan tinggi antioksidan harus cukup, agar tubuh penderita jantugn tidak cepat lelah dan menggunakan massa otot untuk memperoleh energi dan tinggi serat bagi aktifitas kehidupan sehari-harinya (Roza \& Iham, 2017).

Diani (2017) mengatakan bahwa diet yang baik untuk penyakti jantung adalah mengkonsumsi makanan yang mengandung 
protein nabati seperti tahu, tempe, oncom dan kacang-kacangan.

Konsumsi buah-buahan juga baik untuk kesehatan. Beberapa buah baik dikonsumsi oleh penderita jantung koroner seperti jeruk, pisang dan pepaya, dimana buah-buahan ini mengandung Vitamin $\mathrm{C}$. Vitamin $\mathrm{C}$ adalah salah satu komponen dalam pemecahan kolesterol. Vitamin khususnya vitamin C diduga dapat menurunkan taraf trigliserida serum tinggi yang berperan dalam terjadinya penyakit jantung. Vitamin $\mathrm{C}$ sebagai antikosidan yang dapat larut dalam air mencegah terjadinya oksidari. Vitamin C sebagai antiosidan menangkap radikal perioksil sehingga dapat melindungi LDL dari kerusakan osidatif. Kandungan vitamin C yang tinggi dalam darah akan menurunkan kadar kolesterol (Rachmawati, 2016).

\section{SIMPULAN}

Berdasarkan hasil penelitian terhadap pasien yang menjalani prosedur kateterisasi di RSUD Arifin Achmad Provinsi Riau mayoritas berumur antara 45-55 tahun, berjenis kelamin laki-laki, sedangkan tingkat pendidikan pasien yang paling banyak adalah akademi/perguruan tinggi, dan berkerja sebagai wiraswasta. Waktu dilakukan kateterisasi paling banyak di bulan Desember 2018 dengan jumlah sumbatan paling banyak 2 buah sumbatan.

Hasil penelitian aktivitas dan diet pada pasien kateterisasi jantung menunjukkan sebagian besar adanya perubahan. Pola aktivitas sebelum kateterisasi mengalami ketergantungan berat sebanyak 15 orang $(50 \%)$, setelah kateterisasi mandiri sebanyak 30 orang $(100 \%)$. Intensitas aktivitas sebelum dan setelah kateterisasi adalah intensitas ringan sebanyak 17 orang $(56,7 \%)$ menjadi 30 orang $(100 \%)$. Diet makanan berkolesterol sebelum kateterisasi 3-6x/minggu sebanyak 17 orang $(56,7 \%)$ dan setalah kateteriasi jantung 2x/bulan sebanyak 24 orang (80\%). Konsumsi makanan berserat sebelum dan setelah melakukan kateterisasi jantung adalah $3-6 x / m i n g g u$ sebanyak 14 orang $(46,7 \%)$ dan setelah kateterisasi jantung sebanyak 22 orang $(73,3 \%)$. Konsumsi makanan berprotein nabati sebelum dan setelah kateteriasi jantung 
Essa Widya Pertiwi, Erwin, Wan Nishfa Dewi, Gambaran Perubahan Aktivitas dan Diet pada Pasien Post Kateterisasi Jantung

adalah 3-6x/minggu dengan persentase sebelum kateterisasi sebanyak 14 orang $(46,7 \%)$ dan setelah kateterisasi 17 orang $(56,7 \%)$. Konsumsi makanan bervitamin sebelum kateterisasi adalah 1-2x/minggu 23 orang $(76,7 \%)$ dan setelah kateterisasi 3-6x/minggu 18 orang $(60 \%)$. Ini menunjukkan bahwa penderita penyakit jantung koroner perlu memanajemen aktivitas dan diet sehingga terdapat perubahan dalam aktivitas dan diet menjadi lebih baik.

\section{SARAN}

Diharapkan penelitian ini dapat dijadikan sebagai masukan, pembelajaran, acuan bagi perkembangan ilmu keperawatan dan menjadi Evidence Based Practice (EBP) di dunia keperawatan khususnya mengenai aktivitas dan diet pada pasien yang menjalani kateterisasi jantung. Bagi institusi kesehatan dapat memperluas pengetahuan tentang bagaimana aktivitas dan diet pada pasien yang menjalani prosedur kateterisasi jantung sehingga bisa dijadikan acuan untuk meningkatkan pelayanan khususnya melaksanakan implementasi keperawatan.

Penelitian ini dapat dijadikan referensi bagi penelitian selanjutnya khususnya yang berhubungan dengan kateterisasi jantung, Penelitian lanjutan yang dapat dilakukan mengenai pasien yang melakukan tindakan kateterisasi jantung ini adalah penelitian mengenai diet dan status gizi dengan menyertakan lembar obsevasi dan wawancara mendalam.

\section{DAFTAR PUSTAKA}

Al-Muammar, M. El-Shafie \& Feroze,S. (2012). Association between dietary habits and body mass index of adolescent females in intermediate schools in Riyadh, Saudi Arabia. Department of Community Health Sciences. Diperoleh tanggal 5 November 2018 dari https://www.ncbi.nlm.nih.gov/pubmed/24 932932

American Heart Association. (2015). Cardiac catheterization. Diperoleh tanggal 1 November 2018 dari https://www.heart.org/en/health-topics/he art-attack/diagnosing-a-heart-attack/card iac-catheterization

Aryapost, S. (2016). Activities of daily living: ederly. International Journal of Development Research Vol. Diperoleh tanggal 1 November 2018 dari https://www.journalijdr.com 
Dahlan, S. (2010). Besar sampel dan cara pengambilan sampel dalam penelitian kedokteran dan kesehatan. Jakarta: Salemba medika

Diani, G. A. P. (2017). Optimasi komposisi bahan makanan bagi pasien rawat jalan penyakit jantung dengan menggunakan algoritme particle swarm optimization (PSO). Diperoleh pada tanggal 20 Mei 2019 dari http://j-ptiik.ub.ac.id

Hidayat, A., Erwin., \& Dewi, A.P. (2015). Persepsi jantung koroner yang akan dilakukan kateterisasi jantung Diperoleh $\begin{array}{lllll}\text { tanggal } & 15 & \text { Mei } & 2019 & \text { dari }\end{array}$ https://jom.unri.ac.id

Irianto, K. (2014). Epidemiologi penyakit tidak menular dan tidak menular panduan klinis. Bandung : Alvabeta

Iskandar. (2017). Faktor resiko terjadinya penyakit jantung koroner pada pasien rumah sakit umum meuraxa Banda Aceh. AcTion Journal Vol 2 No. 1. Diperoleh tanggal 11 Maret 2019 dari http://ejournal.poltekkesaceh.ac.id

Pradono, J., dan Werdhasari, A. (2018). Faktor Determinan Penyakit Jantung Koroner pada KelompokUmur 25-65 tahun di Kota Bogor, Data Kohor 2011-2012. Diperoleh tanggal 16 Mei 2019 dari http://ejournal.litbang.kemkes.go.id

Rachmawati, (2016). Hubungan asupan vitamin $\mathrm{C}$ dan vitamin $\mathrm{E}$ dengan kadar LDL (Low Density Lipoprotein) pada penderita penyakit jantung koroner di Instalasi Rawat Jalan RSUD DR. Moewardi. Diperoleh pada tanggal 20 Mei 2019 dari http://eprints.ums.ac.id
Roza, A., \& Ilham, M. (2017). Gambaran pengetahuan pasien tentang diet pada penyakit jantung di poli jantung RSUD Arifin Achmad Provinsi Riau. Diperoleh tanggal $20 \quad$ Mei 2019 dari jurnal.univrab.ac.id

Santoso. (2009). Buku ajar ilmu penyakit dalam edisi ke $V$. Jakarta: Internal Publishing

Udjianti, W.J. (2011). Keperawatan kardiovaskuler. Jakarta: Salemba Medika Waspadji, S., Suyono. S., Sukarji, K., \& Kresmawan, T. (2010). Pengkajian status gizi studi epidemiologi. Jakarta: FKUI

Widiyanto, S. (2014). Mengenal 10 penyakit mematikan. Yogyakarta : Insan Madani

World Health Organization. (2015). Physical activity. Diperoleh tanggal 12 Desember 2018 dari https://www.who.int/news-room/fact-sheet s/detail/physical-activity

Zahrawardani, D. (2013). Analisis faktor risiko kejadian penyakit jantung koroner di RSUP Dr Kariadi Semarang. Diperoleh tanggal 20 Mei 2019 dari https://jurnal.unimus.ac.id/index.php/ked okteran/article/view/1341 